\title{
EPIDEMIOLOGICAL SITUATION OF URINARY SCHISTOSOMIASIS IN TAMWAH AREA, GIZA, EGYPT: ASSESSMENT AND CONTROL
}

\section{By}

\author{
SALWA M.A. DAHESH ${ }^{1}$ AND BAHAA ELDEEN FARID ${ }^{2}$
}

General Administration of Endemic Diseases Control of Giza ${ }^{1,2}$, Research Institute of Medical Entomology, The General Organization for Institutes and Teaching Hospitals, Ministry of Health, Dokki, Egypt ${ }^{\top}$ (Salwamohamed970@gmail.com)

\section{Abstract}

Preliminary studies were carried out on schistosomiasis in Giza Governorate for the last three years. These studies revealed that Tamwah village was one of areas afflicted by the highest number of Schistosoma haematobium infection cases. The study assessed the epidemiological situation of $S$. haematobium by parasitological and snail surveys. During April 2016, urine samples of 1285 children collected from three primary schools were centrifuged for microscopic examination. Also a snail survey was done along the shore $(700 \mathrm{~m}$ length). The snail were classified and examined for cercariae by light exposure and crushing. The results revealed that S. haematobium was $4.04 \%$ (52 cases). Majority were males ( $76.9 \%$ out of positive cases), with highly significant. There was a strong correlation between age of children and infection (44.2\%) among oldest children (11 years) lowest (3.8\%) was among the youngest group (6 years). Enterobius vermicularis ova in females' urine samples was $0.54 \%$ ( 7 cases). One was mixed infection with $S$. haematobium. The highest percentage among children infected with $S$. haematobium had pus cells 6- 30/HPF and RBCs less than 100/HPF in urine. There were crystals of uric acid, Ca oxalates and triple phosphate $5.8 \%, 1.8 \% \& 0.8 \%$ respectively. The snails were Lanistes carinatus, Bellamya unicolor, Physa micropleura, Succinia cleopatra, Cleopatra bulimoides, Bulinus trancatus \& Lymnaea natalensis. The commonest was B. trancatus followed by L. natalensis. Builinus spp were positive for schistosomiasis cercaria and Lymnaea spp were positive for virgulate xiphidiocercariae; parasites of bates, birds and amphibians.

Key words: Tamwah village, Giza, S. haematobium, patients, snails, recommendations.

\section{Introduction}

Schistosomiasis is a human disease caused by the parasitic blood flukes of Schistosoma spp. Over 239 million people are chronically or acutely infected with one or more species, suggested that more than 400 million people worldwide may be affected (Rollinson, 1987). Population at risk increased to over 779 million (WHO, 2011) due to changing demographics in endemic countries and anthropogenic changes to the environment occurring via water project development. About 106 million African people were risky for schistosomiasis (Steinmann et al, 2006), estimated about $85 \%$ of infected people (Chitsulo et al, 2000).

The various species of the genus Schistosoma are trematodes of family Schistosomatidae, which are dioecious, digenean multicellular helminthic parasites whose adult habitat the circulatory system of vertebrates. Sixteen species of Schistosoma infect man or animals. Five are responsible for human infections; S. haematobium, S. mansoni, $S$. intercalatum, S. japonicum and S. mekongi (Rollinson et al, 1987). S. haematobium the agent of urogenital schistosomiasis is endemic in fifty three countries in the Middle East and Africa (WHO, 2012) while S. mansoni is the most prevalent species endemic in fifty five countries e.g. Arabia Peninsula, Egypt, Libya, Sudan, Sub-Saharan Africa, Brazil, some Caribbean islands, Venzuela and Suriname (Chitsulo et al, 2000). S. japonicum is endemic in Indonesia, China and the Philippines while $S$. mekongi in several areas of Cambodia and the Lao Peoples' Democratic Republic and $S$. intercalatum is found in rainy areas of Central Africa.

In Egypt $S$. haematobium was endemic since ancient ages (Ruffer, 1910; Deelder et al, 1990; Contis et al, 1996; David, 1997). The first descriptive prevalence pattern was in (1937) by Scott who reported that schisto- 
somiasis was highly prevalent in both the Nile Delta and the Nile Valley South of Cairo in districts where the perennial irrigation system was used. The highest prevalence was recorded in the Northern and Eastern parts of the Delta where $85 \%$ of the population was infected with either one or both species of the parasite. S. mansoni was very low in the Southern part of the Delta and completely absent from the Nile Valley South of Cairo in basin or perennial irrigation system. After Scott's study, several large scale surveys were conducted to record the pattern of schistosomiasis infection. The Nile Delta governorates showed a gradual reduction in the overall prevalence of $S$. mansoni while $S$. haematobium continued to decrease to disappearing completely. In Upper and Middle Egypt governorates, the consistent reduction in the prevalence of $S$. haematobium except in Qena, Sohag and Aswan following the construction of the High Dam was recorded where basin irrigation was converted to perennial irrigation system (Wright, 1973; El Alamy et al, 1977; Miller et al, 1981; Cline et al, 1989; AbdelWahab et al, 1993; Mickelson et al, 1993). Prevalence of $S$. haematobium ranged from $4.8 \%$ to $13.7 \%$ in Upper Egypt (El-Enien et al, 1993; Hammam et al, 2000). In a village of Giza governorate, $S$. haematobium was $7.4 \%$ in harmony results with other Egyptian areas (Kessler et al, 1985; Webbe et al., 1990). The infection was high amongst the villagers especially the primary school children (Talaat et al, 1999). In nine Egyptian Governorates, there was already change in transmission pattern of both species in Lower and Upper Egypt (El Khoby et al, 2000). Ministry of Health and Population (MOH) recorded that only 20 villages in the whole country showed prevalence more than $3.5 \%$ and none would have more than $10 \%$ by the end of 2010. The success in controlling schistosomiasis in Egypt was implemented through several control programs strategy recommended by the WHO. Two factors were responsible for the schistosomiasis pat- tern: the irrigation type used whether perennial or basin. Conversion from basin to perennial irrigation resulted by Aswan High Dam construction and the $\mathrm{MOH}$ control programs (Barakat, 2013). Schistosomiasis persistence in Egypt update, in some areas as Giza Governorate, makes one feel sorrow.

This study aimed to assess the epidemiological situation of $S$. haematobium in Tamwah village, one of Giza villages with highest prevalence rate of $S$. haematobium infection, and try to control such problem through the available measures.

\section{Subjects, Materials and Methods}

A preliminary study on the areas of the highest prevalence of schistosomiasis was done during the last three years. The data were collected tabulated and statistically analyzed. Tamwah is one of villages belonged to Abu Alnomros Center, Giza governorate, lies on the Nile River where its borders are Al-Badrashin Center in the south, Met Shamasi in the west, Manyal Shihah in the north and Nile River in the east. The population about 28,000 in 2016, its location by Global positioning system GPS was 29.939720, 31.265508. There are three primary schools; Fatma Al Zahraa, Osman ben Afaan and Tamwah primary school.

The field studies were carried out during April 2016. (1285) urine samples were collected in $30 \mathrm{ml}$ sterile capped plastic containers from children of three primary schools at morning. Questionnaires about personnel and environmental data were done for each examined child. The urine samples were labeled and transferred to laboratory. $10 \mathrm{ml}$ of the specimen lower part was poured into new tube for centrifugation, examined microscopically by $10 \& 40 \mathrm{X}$ power lenses.

Snails sampling was conducted in April 2016, in sites where there was major human water contact along the shores of small branch of Nile River. The screened shore length was $700 \mathrm{~m}$. Sampling was carried out by 2 trained field collectors using standard snail scoops or occasionally hand collection. Sampling time was between 08:30 hr. \& 
10:30 hr. Snails from each site were labeled and transported in separate perforated plastic containers to the laboratory and processed. Snails were identified to species level based on morphological characters using standard keys (Brown, 1994; WHO, 1998). Snails were placed individually in 24-well culture plates containing $1 \mathrm{ml}$ of clear, filtered water (same source as site of collection) and exposed to indirect sunlight for $4 \mathrm{hr}$ to induce cercarial shedding. The time of cercariae shedding was carefully selected to coincide with the early peak shedding time (midday) (Steinauer et al, 2008). Wells were exam- ined for cercariae under a dissecting microscope. Those did not shed cercariae within a month were crushed and examined. Recovered cercariae were fixed in $70 \%$ ethanol for identification (Frandsen et al, 1984).

Statistical analyzed: Using SPSS version 20 (IBM, Inc. New York, USA). Chi-square test was chosen to compare differences of varies factors in the distribution of Schistosomiasis. Those who did not bring sample were excluded. The 0.05 cut-off value was used as a criterion for significance. All tests were interpreted in a two-tailed fashion (Lehmann, 1975, Altman, 1992).

\section{Results}

The results were shown in tables (1 to 8 ) and photos (1 to 9).

Table 1: Parasites in persons' urine samples according to sex in Tamwah village, Giza Governorate.

\begin{tabular}{|c|c|c|c|c|c|c|}
\hline \multicolumn{2}{|c|}{ Sex } & Normal & S. haematobium +ve & E.vermicularis $+\mathrm{ve}$ & Both parasites +ve & Total \\
\hline \multirow[b]{2}{*}{ Male } & No. & 651 & 40 & 0 & 0 & 691 \\
\hline & $\%$ & $94.2 \%$ & $5.8 \%$ & $0.0 \%$ & $0.0 \%$ & $100.0 \%$ \\
\hline \multirow{2}{*}{ Female } & No. & 576 & 11 & 6 & 1 & 594 \\
\hline & $\%$ & $97.0 \%$ & $1.9 \%$ & $1.0 \%$ & $0.2 \%$ & $100.0 \%$ \\
\hline \multirow{2}{*}{ Total } & No. & 1227 & 51 & 6 & 1 & 1285 \\
\hline & $\%$ & $95.5 \%$ & $4.0 \%$ & $0.5 \%$ & $0.1 \%$ & $100.0 \%$ \\
\hline
\end{tabular}

Pearson Chi-Square $=20.959, \mathrm{P}<0.01$

Table 2: S. haematobium in persons' urine samples according to sex.

\begin{tabular}{|c|c|c|c|c|c|}
\hline \multicolumn{3}{|c|}{ Sex } & Normal & S. haematobium +ve & Total \\
\hline \multirow{2}{*}{ Male } & No. & 651 & 40 & 691 \\
\cline { 2 - 5 } & $\%$ & $52.8 \%$ & $76.9 \%$ & $53.7 \%$ \\
\hline \multirow{2}{*}{ Female } & No. & 582 & 12 & 594 \\
\cline { 2 - 5 } & $\%$ & $47.2 \%$ & $23.1 \%$ & $46.2 \%$ \\
\hline \multirow{2}{*}{ Total } & No. & 1233 & 52 & 1285 \\
\cline { 2 - 5 } & $\%$ & $100.0 \%$ & $100.0 \%$ & $100.0 \%$ \\
\hline
\end{tabular}

\begin{tabular}{|l|c|c|c|}
\hline Tests & Value & df & Asymp. Sig. (2-sided) \\
\hline Pearson Chi-Square & 11.76 & 2 & .003 \\
\hline Likelihood Ratio & 12.56 & 2 & .002 \\
\hline Linear-by-Linear Association & 9.71 & 1 & .002 \\
\hline N of Valid Cases & 1285 & & \\
\hline
\end{tabular}

Table 3: Parasites in persons' urine samples according to age

\begin{tabular}{|c|c|c|c|c|c|c|}
\hline \multicolumn{2}{|c|}{ Age in years } & Normal & S. haematobium +ve & E.vermicularis $+\mathrm{ve}$ & Both parasites +ve & Total \\
\hline \multirow{2}{*}{6} & No. & 376 & 2 & 0 & 0 & 378 \\
\cline { 2 - 7 } & $\%$ & $99.5 \%$ & $0.5 \%$ & $0.0 \%$ & $0.0 \%$ & $100.0 \%$ \\
\hline \multirow{3}{*}{7} & No. & 399 & 2 & 5 & 0 & 406 \\
\cline { 2 - 7 } & $\%$ & $98.3 \%$ & $0.5 \%$ & $1.2 \%$ & $0.0 \%$ & $100.0 \%$ \\
\hline \multirow{2}{*}{8} & No. & 115 & 6 & 1 & 1 & 123 \\
\cline { 2 - 7 } & $\%$ & $93.5 \%$ & $4.9 \%$ & $0.8 \%$ & $0.8 \%$ & $100.0 \%$ \\
\hline \multirow{2}{*}{9} & No. & 156 & 11 & 0 & 0 & 167 \\
\cline { 2 - 7 } & $\%$ & $93.4 \%$ & $6.6 \%$ & $0.0 \%$ & $0.0 \%$ & $100.0 \%$ \\
\hline \multirow{2}{*}{10} & No. & 91 & 7 & 0 & 0 & 98 \\
\cline { 2 - 7 } & $\%$ & $92.9 \%$ & $7.1 \%$ & $0.0 \%$ & 0 & $100.0 \%$ \\
\hline \multirow{2}{*}{11} & No. & 90 & 23 & $0.0 \%$ & $0.0 \%$ & $100.0 \%$ \\
\cline { 2 - 7 } & $\%$ & $79.6 \%$ & $20.4 \%$ & 6 & 1 & 1285 \\
\hline \multirow{2}{*}{ Total } & No. & 1227 & 51 & $0.5 \%$ & $0.1 \%$ & $100.0 \%$ \\
\cline { 2 - 7 } & $\%$ & $95.5 \%$ & $4.0 \%$ & & & \\
\hline
\end{tabular}

Pearson Chi-Square $=128.19, \mathrm{P}<0.01$ 
Table 4: S.haematobium in persons' urine samples according to age.

\begin{tabular}{|c|c|c|c|c|}
\hline \multicolumn{2}{|l|}{ Age } & Normal & S. haematobium +ve & Total \\
\hline \multirow{2}{*}{6} & No. & 376 & 2 & 378 \\
\hline & $\%$ & $30.5 \%$ & $3.8 \%$ & $29.4 \%$ \\
\hline \multirow{2}{*}{7} & No. & 404 & 2 & 406 \\
\hline & $\%$ & $32.8 \%$ & $3.8 \%$ & $31.6 \%$ \\
\hline \multirow{2}{*}{8} & No. & 116 & 7 & 123 \\
\hline & $\%$ & $9.4 \%$ & $13.5 \%$ & $9.6 \%$ \\
\hline \multirow{2}{*}{9} & No. & 156 & 11 & 167 \\
\hline & $\%$ & $12.7 \%$ & $21.2 \%$ & $13.0 \%$ \\
\hline \multirow{2}{*}{10} & No. & 91 & 7 & 98 \\
\hline & $\%$ & $7.4 \%$ & $13.5 \%$ & $7.6 \%$ \\
\hline \multirow{2}{*}{11} & No. & 90 & 23 & 113 \\
\hline & $\%$ & $7.3 \%$ & $44.2 \%$ & $8.8 \%$ \\
\hline \multirow{2}{*}{ Total } & No. & 1233 & 52 & 1285 \\
\hline & $\%$ & $100.0 \%$ & $100.0 \%$ & $100.0 \%$ \\
\hline
\end{tabular}

Pearson Chi-Square $=108.693$

\begin{tabular}{|l|c|c|c|}
\hline \multicolumn{1}{|c|}{ Test } & Value & df & Asymp. Sig. (2-sided) \\
\hline Pearson Chi-Square & 108.693 & 5 & .000 \\
\hline Likelihood Ratio & 85.775 & 5 & .000 \\
\hline Linear-by-Linear Association & 87.858 & 1 & .000 \\
\hline
\end{tabular}

Table 5: Parasites in persons' urine samples according amount of blood in specimens.

\begin{tabular}{|c|c|c|c|c|c|c|c|}
\hline Urine & \multicolumn{2}{|c|}{ less than 5/HPF } & $6-30 / \mathrm{HPF}$ & \multirow{2}{*}{\multicolumn{2}{|c|}{\begin{tabular}{|c|} 
over $30 / \mathrm{HPF}$ \\
3
\end{tabular}}} & over 100/HPF & Total \\
\hline \multirow{2}{*}{ Normal } & No. & 1209 & 12 & & & 0 & 1224 \\
\hline & $\%$ & $98.8 \%$ & $1.0 \%$ & \multicolumn{2}{|c|}{$0.2 \%$} & $0.0 \%$ & $100.0 \%$ \\
\hline \multirow{2}{*}{ S. haematobium +ve } & No. & 10 & 17 & \multicolumn{2}{|c|}{15} & 9 & 51 \\
\hline & $\%$ & $19.6 \%$ & $33.3 \%$ & \multicolumn{2}{|c|}{$29.4 \%$} & $17.6 \%$ & $100.0 \%$ \\
\hline \multirow{2}{*}{ E.vermicularis + ve } & No. & 4 & 1 & \multicolumn{2}{|c|}{1} & 0 & 6 \\
\hline & $\%$ & $66.7 \%$ & $16.7 \%$ & \multicolumn{2}{|c|}{$16.7 \%$} & $0.0 \%$ & $100.0 \%$ \\
\hline \multirow{2}{*}{ Both parasites $+v e$} & No. & 0 & 0 & \multicolumn{2}{|c|}{1} & 0 & 1 \\
\hline & $\%$ & $0.0 \%$ & $0.0 \%$ & \multicolumn{2}{|c|}{$100.0 \%$} & $0.0 \%$ & $100.0 \%$ \\
\hline \multirow{2}{*}{ Total } & No. & 1223 & 30 & \multicolumn{2}{|c|}{20} & 9 & 1282 \\
\hline & $\%$ & $95.4 \%$ & $2.3 \%$ & \multicolumn{2}{|c|}{$1.6 \%$} & $0.7 \%$ & $100.0 \%$ \\
\hline \multicolumn{8}{|c|}{ Pearson Chi-Square $=813.23, \mathrm{P}<0.01$} \\
\hline \multicolumn{3}{|c|}{ Test } & Value & $\mathrm{df}$ & & . Sig. (2-sided) & \\
\hline \multicolumn{3}{|c|}{ Pearson Chi-Square } & 813.234 & 9 & \multicolumn{2}{|c|}{$\begin{array}{c}\text { Asymp. Sig. (L-sided) } \\
0.000\end{array}$} & \\
\hline \multicolumn{3}{|c|}{ Likelihood Rati } & 271.053 & 9 & & 0.000 & \\
\hline \multicolumn{3}{|c|}{ Linear-by-Linear Association } & 567.836 & 1 & & 0.000 & \\
\hline & \multicolumn{2}{|c|}{$\mathrm{N}$ of Valid Cases } & 1282 & & & & \\
\hline
\end{tabular}

Table 6: Parasites in persons' urine samples according according to amount of pus cells in specimens.

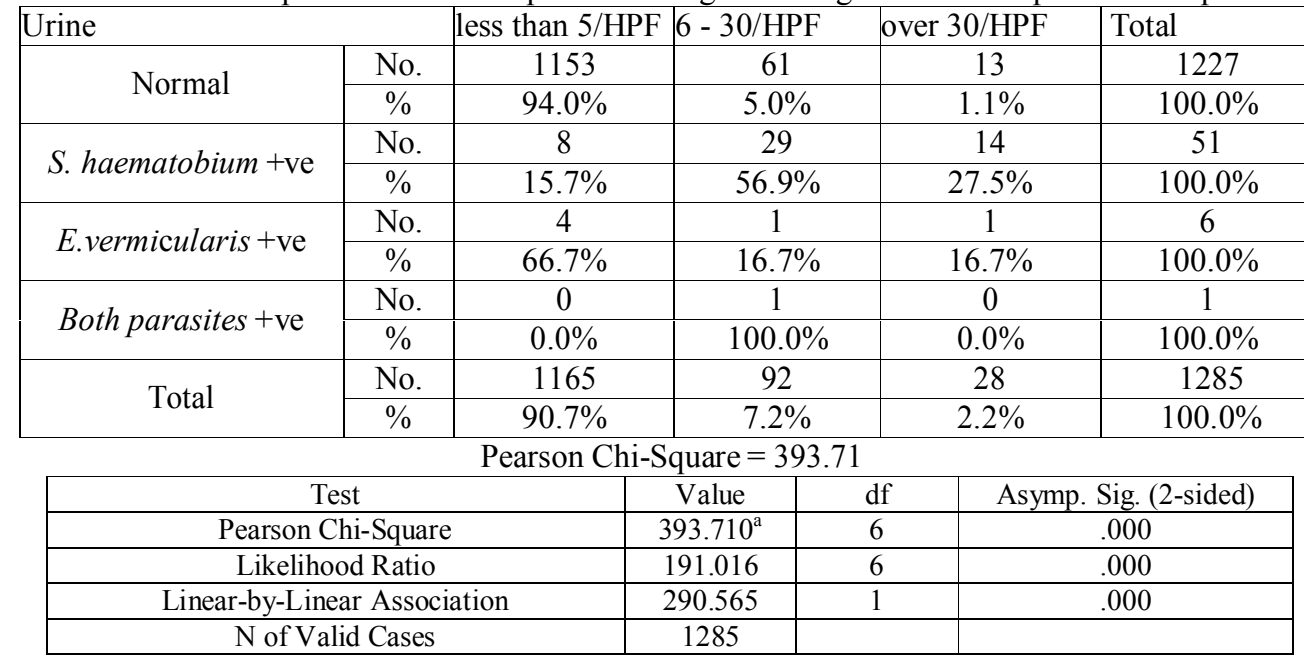


Table 7: Types of crystals in persons' urine samples according to age.

\begin{tabular}{|c|c|c|c|c|c|c|}
\hline \multicolumn{2}{|c|}{ Age in years } & Nil & uric acid & Ca. Oxalates & Triple phosphate & Total \\
\hline \multirow{2}{*}{6} & No. & 354 & 17 & 3 & 4 & 378 \\
\cline { 2 - 7 } & $\%$ & $93.7 \%$ & $4.5 \%$ & $0.8 \%$ & $1.1 \%$ & $100.0 \%$ \\
\hline \multirow{2}{*}{7} & No. & 359 & 31 & 12 & 4 & 406 \\
\cline { 2 - 7 } & $\%$ & $88.4 \%$ & $7.6 \%$ & $3.0 \%$ & $1.0 \%$ & $100.0 \%$ \\
\hline \multirow{2}{*}{8} & No. & 113 & 8 & 1 & 1 & 123 \\
\cline { 2 - 7 } & $\%$ & $91.9 \%$ & $6.5 \%$ & $0.8 \%$ & $0.8 \%$ & $100.0 \%$ \\
\hline \multirow{2}{*}{9} & No. & 156 & 8 & 2 & 1 & 167 \\
\cline { 2 - 7 } & $\%$ & $93.4 \%$ & $4.8 \%$ & $1.2 \%$ & $0.6 \%$ & $100.0 \%$ \\
\hline \multirow{2}{*}{10} & No. & 88 & 7 & 3 & 0 & 98 \\
\cline { 2 - 7 } & $\%$ & $89.8 \%$ & $7.1 \%$ & $3.1 \%$ & $0.0 \%$ & $100.0 \%$ \\
\hline \multirow{2}{*}{11} & No. & 107 & 4 & 2 & 0 & 113 \\
\cline { 2 - 7 } & $\%$ & $94.7 \%$ & $3.5 \%$ & $1.8 \%$ & $0.0 \%$ & $100.0 \%$ \\
\hline \multirow{2}{*}{ Total } & No. & 1177 & 75 & 23 & 10 & 1285 \\
\cline { 2 - 7 } & $\%$ & $91.6 \%$ & $5.8 \%$ & $1.8 \%$ & $0.8 \%$ & $100.0 \%$ \\
\hline
\end{tabular}

Pearson Chi-Square $=15.326, \mathrm{P}>0.01$

\begin{tabular}{|l|c|c|c|}
\hline Test & Value & df & Asymp. Sig. (2-sided) \\
\hline Pearson Chi-Square & 15.326 & 15 & .428 \\
\hline Likelihood Ratio & 17.087 & 15 & .314 \\
\hline
\end{tabular}

Table 8: S. haematobium in persons' urine samples according to contact with Nile water.

\begin{tabular}{|c|c|c|c|c|}
\hline \multicolumn{2}{|c|}{ Water contact } & Normal & Positive for S. haematobium & Total \\
\hline \multirow{2}{*}{ yes } & No. & 199 & 39 & 238 \\
\cline { 2 - 5 } & $\%$ & $16.1 \%$ & $75.0 \%$ & $18.5 \%$ \\
\hline \multirow{2}{*}{ No } & No. & 1034 & 13 & 1047 \\
\cline { 2 - 5 } & $\%$ & $83.9 \%$ & $25.0 \%$ & $81.5 \%$ \\
\hline \multirow{2}{*}{ Total } & No. & 1233 & 52 & 1285 \\
\cline { 2 - 5 } & $\%$ & $100.0 \%$ & $100.0 \%$ & $100.0 \%$ \\
\hline
\end{tabular}

Pearson Chi-Square $=114.55, \mathrm{P}<0.01$

\begin{tabular}{|l|c|c|c|c|c|}
\hline \multicolumn{1}{|c|}{ Test } & Value & df & Asymp. Sig. (2-sided) & Exact Sig. (2-sided) & Exact Sig. (1-sided) \\
\hline Pearson Chi-Square & 114.550 & 1 & 0.000 & & \\
\hline Continuity Correction & 110.682 & 1 & 0.000 & & \\
\hline Likelihood Ratio & 83.170 & 1 & 0.000 & & 0.000 \\
\hline Fisher's Exact Test & & & & & \\
\hline Linear-by-Linear Association & 114.461 & 1 & 0.000 & & \\
\hline N of Valid Cases & 1285 & & & & \\
\hline
\end{tabular}

\section{Discussion}

The present results revealed that the prevalence of $S$. haematobium infection among school children was $4.04 \%$ (52 cases). The result agreed greatly with estimates that mentioned that $S$. haematobium was steadily decreasing for more than a decade in Middle and Upper Egypt (Miller et al, 1981; Kitron et al, 1985) and disappeared from Nile Delta (Cline et al, 1989; Barakat et al, 1995).

The prevalence of $S$. haematobium infection was $(7.4 \%)$ in the village of El-Gezira El-Shakra, El Saf district, Giza Governorate in Upper Egypt. The prevalence of the population sample and school children was $7.4 \%$ and $10.6 \%$, respectively (Talaat et al, 1999). The results agreed with other areas of Egypt
(Kessler et al, 1987; Webbe et al, 1990). Urinary schistosomiasis prevalence was similar in magnitude to cross-sectional reports from representative samples in 1993. The prevalence of $S$. haematibium were $8.9 \%$ in Al-Minya, 5.2\% in Assiut and 5.4\% Qena Governorates (El-Enien et al, 1993; Hammam et al, 1993a; b) respectively. Although the elucidation of this decrease remains to be defined, chronologically, the decrease was first noted almost a decade after closure of the High Dam (Miller et al, 1978a,b)

The present study showed that most of cases were males $(76.9 \%$ out of positive cases) frequent attending to water for swimming, fishing, washing and cleaning their animals in Nile water while female children were 
contact with Nile water during aiding their mothers in cleaning dishes, clothes, carpets ...etc. The difference betw- een males and females was highly significant. Also showed a strong correlation between age of children and infection where the highest prevalence rate $(44.2 \%)$ was among oldest children (11 years) while the lowest $(3.8 \%)$ was among the youngest group (6 years). There was a strong correlation between schistosomiasis infections and frequent contact with Nile water reflected the high frequency of older children in swimming and fishing in Nile.

The present results agreed with Talaat et al. (1999) who reported that the prevalence of $S$. haematobium infection among children was higher than among adult. Also males were highly infected more than females in a village in Giza Governorate. During childhood in endemic areas, it was found that both prevalence and intensity of Schistoso$m a$ infection increase with age due to continuing exposure to high-risk water bodies. This increasing infectious burden was associated with a parallel increase in morbidity. This is due to the acute inflammation that induced by the about $50 \%$ of parasite eggs that remain trapped in the body (Chen et al, 1989; Smith et al, 1986). Maximum egg excretion peaks were among children between 12-15 years of age (King et al, 2006)

In any event, local transmission is particularly favored because of children passed highest egg output in feces or urine and consistently more likely to be indiscriminate because of urination and defecation habits. They contribute in enhancing perpetuation of the local transmission cycle (WHO, 2002). Schistosoma eggs have been found in the stool or urine of children as young as 2 years old, provoking questions about the true age of onset of disease caused by Schistosoma infection, particularly with regard to the age targets of current population-based control program, now focused on school age children; 5-15 years ages (WHO, 2002). More studies will be needed for defining this issue (Bosompem et al, 2004; Odogwu et al, 2006)

The present work showed that the percentage of presence of Entrobius vermicularis ova in urine samples was $0.54 \%$ (7 cases), all of them were females. One of them had mixed infection with $S$. haematobium. The number of these cases here did not reflect the true prevalence of infection with $E$. vermicularis because these ova were accidently found in urine samples of females. Stool examination has little practical use in detection of such parasite where eggs are found in the feces of about $5-15 \%$ of infected individuals. The recommended methods for detecting the eggs of E. vermicularis were the scotch tape and the sell-tape swab methods (Brooker et al, 2014)

The highest percentage among children infected with $S$. haematobium had pus cells 6-30/HPF and red blood cells less than $100 / \mathrm{HPF}$ in their urine samples. That may reflect the moderate no. of parasites in the infected children where the highest count of eggs/ precipitate of $10 \mathrm{ml}$ urine did not exceed 10 eggs. So the microscopic examiner should take into consideration the low burden of parasites among people and does not neglect the normal samples that do not contain red blood cells or white blood cells where the percentage of clear and normal urine samples containing $S$. haematobium ova was $19.6 \%$ out of all positive cases.

Other findings in urine samples of the children was the crystals where the parentages of urine samples contained crystals of uric acid, ca oxalates and triple phosphate were $5.8 \%, 1.8 \%$ and $0.8 \%$ respectively. The reports of urine samples were referred to specialist in Tamwah Unit for treating and follow up the children.

Tamwah village lacks good sanitation where people use trenches instead. People were suffering from odor and taste of drinking water. They prefer using Nile water in washing clothes, dishes, carpets...etc. daily for avoiding filling their trenches with waste water because of relative expensive cost re- 
quired for empting them. Transmission is significantly linked to areas characterized by underdevelopment and lack of sanitation (Bruun et al, 2008) where the perpetuation of parasite life cycle requires water contaminated with human sewage as well as suitable environmental conditions (King, 2001). Also consistent exposure to reinfection is highly associated with a lack of safe water sources for agricultural, domestic and recreational activities (Bruun et al, 2008). Schistosomiasis is a preventable disease of poverty, most prevalent in rural areas, unplanned peri-urban areas and also is common among refugee camps where transmission is highly difficult to be controlled (Barbosa et al, 2010) (Ugbomoiko et al, 2010).

The collected snail species were Lanistes carinatus, Bellamya unicolor, Physa acuta, Cleopatra bulimoides, Bulinus trancatus, Succinia cleopatra and Limnaea cailliaudi. No snails belonged to Biomphalaria alexandrina were found. The most abundant species was B. trancatus followed by $L$. natalensis. No snails belonged to Biomphalaria alexandrina were found.

Twenty eight species of snails were known to exist in Egypt (Lotfy et al, 2015). The $\mathrm{MOH}$ records showed that Bulinus truncatus and Biomphalaria alexandrina, were present from 1991 to 1995 while B. alexandrina was more abundant than B. truncatus in the canals surrounding of El-Gezira El-Shakra village, El Saf district, Giza Governorate (Talaat et al, 1999). Thirteen species in different water courses in Egypt during two successive years were B. truncatus, Biomphalaria alexandrina, Physa acuta, Helisoma duryi, L. natalensis, Cleopatra bulimoides, Planorbis pantries, Lanistes carinatus, Bellamya unicolor, Melanoides tuberculata, Succinia Cleopatra, Theodoxus niloticus and Valvata nilotica. B. alexandrina was most abundant during spring and autumn represented by 14 \& 26 snails/site, respectively while B. truncatus was most abundant during winter (7.7 $\& 3.6$ snails/site) during the two years, respectively. Lyminaea spp was represented by 7 snails/site in summer (Khayat et al, 2011).

The present result revealed that $10.8 \%$ (8 out of 74 collected snails) of Builinus spp were positive for furcocercus cercaria of $S$. haematobium and 5\% (2 out of 40 collected snails) of Lymnaea spp were positive for virgulate xiphidiocercariae which are the intestinal parasites of bates, birds and amphibians. Virgulate xiphidiocercaria is characterized by the leptocercus tail which is shorter than that of Faschiola spp. Its oral sucker contains bilobed or pyriform virgula organ. The differentiation between different types of cercariae found in the snails was demonstrated (Frandsen et al, 1984).

Three control measures were achieved during and after this study. Health education of school children and people during collection of urine samples and during snail survey has been done. After collection of snails, an aquatic bulldozer removed the heavy growth vegetation found on the surface water of Nile. Mass treatment with praziquantel for population above 5 years was carried out by General Administration of Endemic Diseases Control of Giza and under supervision of General Administration of Endemic Diseases Control of Ministry of Health. The consensus of population of Tamwah village is 28000 inhabitants, 23000 of them are above 5 years. The number of individual received treatment was $17547(76.29 \%$ of total targeted group) where other people were outside of the village at time of mass treatment.

Praziquantel is effective against all human Schistosoma species. It is also effective in the other snail-borne trematode infections as paragonimiasis and infections due to the adult cestodes, Taenia solium, T. saginata, Hymenolepis nana and Diphyllobothrium spp. The main aim of mass treatment is to reduce the average burden of Schistosoma infection to great extent. Individual 'cure' may or may not occur. But, in some endemic areas, the community might benefit totally by an important 'externality' of mass treatment-the blocking of egg-miracidium-snail 
stages, that diminishes transmission by reducing or minimizing cercarial pollution in water supplies (King et al, 2011; Ozier, 2011). Although PZQ dosage was standardized in large-scale morbidity control programs (WHO, 2002) there was variation in treatment dose for individual patient (Anonymous, 2010). In control programmes although a single oral dose of $40 \mathrm{mg} / \mathrm{kg}$ is effective in S. haematobium and S. mansoni, it was found that higher than usual doses of PZQ was needed to effectively decrease infection levels in some areas of Egypt and Senegal (Danso-Appiah et al, 2002). PZQ mass treatment was the schistosomiasis solution in endemic areas but only if regularly repeated (Almorshidy et al, 2015). Also, combination of PZQ with artemether in the mass treatment gave high chance for killing all parasite immature rather than mature ones (Almorshedey et al, 2016).

Although the Egyptian lows prevent using molluscicides in Nile River, using molluscicides in the control program of schistosomiasis still offers the greatest opportunity for rapid control of transmission. The advantage of using molluscicides is that its use is not requiring the active cooperation of the population as in case of mass treatment or health education. An advantage of considerable importance is that the use of molluscicides controls the vectors of other animal trematode infections which are of economic importance, especially fascioliasis, so it contributes greatly in protection of the animal health (King et al, 2015).

During studying the geography of Tamwah area, it was noticed that there is a narrow branch from Nile constituting the main source of infection. That branch is V-shaped with one ended side so people used it as a basin for swimming where the speed of its water stream is much slower than the main canal. The shape of blunted end of that canal inspire us an idea or suggestion for establishing fish farm in the ended side of that branch and bordering it by strong fence for preventing people from using infected water.
Also swimming pool inside the youth center of the village should be constructed as an alternative place instead of Nile. Other critical problems should be solved to decrease transmission as lack of sanitation and good drinking water.

\section{Recommendations}

Although using molluscicides in the control program of schistosomiasis give the greatest opportunity for rapid control of transmission, Egyptian lows incriminate using such chemicals in Nile River. So, the available control measures of schistosomiasis are restricted in mainly three measures; First, health education. Second, mass treatment. Also timing and regular repeating mass treatment are very important. Third, mechanical removing of aquatic vegetation from Nile should be regular with less than two week interval in between. The idea or suggestion for establishing fish farm in the ended side of Nile branch and bordering it by strong fence for preventing people from using infected water should be achieved. Also swimming pool inside the youth center of the village should be constructed as an alternative place instead of Nile. Other critical problems should be solved as lack of sanitation and good drinking water. At research level studying the safe dose for radiating the infected Nile to kill cercariae instead of panned molluscicides is very important.

\section{Acknowledgements}

The authors would like to thank Prof. Dr. Ayat Atef M. Haggag, Undersecretary for Endemic Diseases, Ministry of Health and Population. Thanks are also due to; Dr. Ahmed Azzam and all members of Environment department, National Institute of Tudor bilharze. Also Dr. Mohammed Ali, Mr. Ebid Ibrahim and all members of Tamwah Unit.

\section{References}

Abdel-Wahab M., Yosery, A, Narooz, S, Esmat, G, El Hak, S, et al, 1993: Is Schistosoma mansoni replacing Schistosoma haematobium in Al-Fayoum? Am. J. Trop. Med. Hyg. 49, 6:697700.

Altman, D, 1992: Practical statistics for medical research $1^{\text {st }}$ ed London: Champman and Hall 
Barakat, R, 2013: Epidemiology of Schistosomiasis in Egypt: Travel through Time: Review. J. Adv. Res. 4, 5:425-32.

Barakat, R, Farghaly, A, El-Masry, AG, ElSayed MK, Husein, MH, Miller FD, 1995: Schistosoma mansoni in the Nile Delta, Egypt: a large scale epidemiological study in Kafr El Sheikh Governorate. Trop. Geogr. Med .47: 25965.

Barbosa, CS, Araujo, KC, Sevilla, MA, et al, 2010: Current epidemiological status of schistosomiasis in the state of Pernambuco, Brazil. Mem. Inst. Oswaldo Cruz 105, 4:549-54.

Brooker, SJ, Bundy, D, 2014: Soil-Transmitted Helminthes (Geohelminths) in Manson's Tropical Disease. 23 Edition.

Brown, DS, 1994: Freshwater snails of Africa and their Medical importance. 2 edition. London: Taylor and Francis;

Bruun, B, Aagaard-Hansen, J, 2008: The Social Context of Schistosomiasis and Its Control. WHO, Geneva.

Chitsulo, L, Engles, D, Montresor, A, Savioli, L, 2000: The global status of schistosomiasis and its control. Acta Trop. 77:41-51.

Cline, BL, Richards, FO, El Alamy, MA, El Hak, S, Ruiz-Tiben, E, et al, 1989: Nile delta schistosomiasis survey: 48 years after Scott. Am. J. Trop. Med. Hyg. 41:56-62.

Contis, G, David, A, 1996: The epidemiology of bilharzia in ancient Egypt: 5000 years of schistosomiasis. Parasitol. Today 12:253-5.

David, A, 1997: Disease in Egyptian mummies: Contribution of new technologies. Lancet 349: 1760-3.

Deelder, A, Miller, N, De Longe, M, Krijker, F, 1990: Detection of schistosome antigen in mummies. Lancet 335:724-5.

El Alamy, M, Cline, B, 1977: Prevalence and intensity of Schistosoma haematobium and $S$. mansoni infection in Qalyub, Egypt. Am. J. Trop. Med. Hyg. 26:470-2.

El Khoby, T, Galal, N, Fenwick, A, Barakat, R, El Hawy, A, et al, 2000: The epidemiology of schistosomiasis in Egypt: Summary findings in nine governorates. Am. J. Trop. Med. Hyg. 62, 2:S88-99.

El-Enien, M, Orieby, A, Shawky, E, Saad, A, Shokrani, N, et al, 1993: Schistosomiasis in Egypt: prevalence, intensity and morbidity in El Minia Governorate. Int. Conf. Schistosomiasis. Vol. 1. Cairo: The Schistosomiasis Research Project, 207.
El-Khayat, HM, Ismail, NM, Mahmoud, KM, Ragb, FM, El-Said, KM, et al, 2011: Evaluation of some chemical parameters as potential determinants of fresh water snails with special reference to medically important snails in Egypt: World Academy of Science, Engineering and Technology. Int. J. Biol. Biomol. Agric. Food Biotechnol.Engineer. 5, 11:797-810.

Elmorshedy, H, Berqguist, R, Abou El-Ela, N E, Eassa, SM, et al, 2015: Can human schistosomiasis mansoni control be sustained in high risk transmission foci in Egypt? Parasites Vectors 8:372-8.

Elmorshedy, H, Tanner, M, Berqguist, RN, Saraf, S, Baracat, R, 2016: Prophylactic effect of artemether on human schistosomiasis mansoni among Egyptian children: A randomized controlled trial. Acta Trop.158:52-8.

Frandsen, F, Christensen, N, 1984: An introductory guide to the identification of cercariae from African freshwater snails with special reference to cercariae of trematode species of medical and veterinary importance. Acta Trop. 41, 2: 181-202.

Hammam, H, Allam, F, Moftah, F, Abdel-Aty, M., Hany, A, et al, 1993a: Schistosomiasis in Egypt: prevalence, intensity and morbidity in the Assiut Governorate. Int. Conf. Schistosomiasis. Vol.1. Cairo: The Schistosomiasis Research Project, 202.

Hammam, H, Allam, F, Moftah, F, Abdel-Aty, M., Hany, A, et al, 1993b: Schistosomiasis in Egypt: prevalence, intensity and morbidity in the Qena Governorate. Int. Conf. Schistosomiasis. Vol.1. Cairo: The Schistosomiasis Research Project, 203.

Hammam, H, Allam, F, Moftah, F, Abdel-Aty, M., Hany, A, et al, 2000a: The Epidemiology of schistosomiasis in Egypt: Assiut Governorate. Am. J. Trop. Med. Hyg. 62, 2:S73-9.

Hammam, M, Zarzour, A, Moftah, F, AbdelAty, M, Hany, A, et al, 2000: The Epidemiology of schistosomiasis in Egypt: Qena Governorate. Am. J. Trop. Med. Hyg. 62, 2:S80-7.

Kessler, PN, Southgate, BA, Klumpp, RK, Mahmoud, M, Remstrand, LG, et al, 1987: Report of an independent evaluation mission on the national bilharzia control program, Egypt, 1985 (abridged version). Trans. R. Soc. Trop. Med. Hyg. 81:1-57.

King, CH, 2001: Epidemiology of schistosomiasis: Determinants of transmission of infection. 
In: Schistosomiasis. Mahmoud AAF, ed., London: Imperial College Press.

King, CH, Bertsch, D, 2015: Historical Perspective: Snail control to prevent schistosomiasis. PLOS Neglected Tropical Diseases Doi: 10.1371/journal.pntd. 0003657 April 23.

Kitron, UD, Higashi, GI, 1985: Schistosoma haematobium in Upper Egypt: analysis of dispersion patterns. Am. J. Trop. Med. Hyg. 34: $331-40$.

Lehmann, E, 1975: Non-Parametric Statistical Method Based on Rank. $1^{\text {st }}$ ed. San Francisco.

Lotfy, WM, Lotfy, LM, 2015: Synopsis of the Egyptian freshwater snail fauna. Folia Malacol. 23, 1:19-40.

Mickelson, M, Azziz, F, Gamil, F, Wahid, A, Richards, F, et al, 1993: Recent trends in the prevalence and distribution of schistosomiasis in the Nile Delta region. Am. J. Trop. Med. Hyg. 49, 1:76-87.

Miller, F, Hussein, M, Mancy, K, Hilbert, M S, 1978a: Aspects of environmental health impacts of the Aswan high dam on rural population in Egypt. Prog. Wat. Tech. 11:173-80.

Miller, F, Hussein, M, Mancy, K, Hilbert, M S, 1978b: Schistosomiasis in rural Egypt: A report of U.S.-Egyptian River Nile and Lake Nasser Research Project. Athens, GA: U.S. Environmental Protection Agency.

Miller, F, Hussein, M, Mancy, K, Hilbert, M S, Monto, AS, Barakat, RMR, 1981: An epidemiological study of Schistosoma haematobium and Schistosoma mansoni infection in thirty-five rural Egyptian villages. Trop. Geogr. Med. 33: 355-65.

Rollinson, D, Southgate, V, 1987: The genus Schistosoma: A taxonomic appraisal. In: Rollinson D, Simpson AJ, editors: The Biology of Schistosomes from Genes to Latrines. London: Academic Press.

Ruffer, M, 1910: Note on the presence of "Bilharzia haematobia" in Egyptian mummies of the twentieth dynasty. Br. Med. J. 1:169.
Savioli, L, Renganathan, E, Montresor, A, Davis, A, Behbehani, K, 1997: Control of schistosomiasis: A global picture. Parasitol. Today 13:444-8.

Scott, J, 1937: The incidence and distribution of the human schistosomiasis in Egypt. Am. J. Trop. Med. Hyg. 25:566-614.

Steinauer, ML, Mwangi, IN, Maina, GM, Kinuthia, JM, Mutuku, MW, et al, 2008: Interactions between natural populations of human and rodent schistosomes in the Lake Victoria region of Kenya: A molecular epidemiological approach. PLoS Negl. Trop. Dis. 2:e222-9.

Steinmann, P, Keiser, J, Bos, R, et al, 2006: Schistosomiasis and water resources development systematic review, meta-analysis and estimates of people at risk. Lancet Infect. Dis. 6, 7:411-25

Talaat, M, El-Ayyat, A, Sayed, H, Miller, F, 1999: Emergence of Schistosoma mansoni infection in Upper Egypt: the Giza governorate. Am. J. Trop. Med. Hyg. 60, 5:822-6.

Ugbomoiko, US, Ofoezie, IE, Okoye, IC, et al, 2010: Factors associated with urinary schistosomiasis in two peri-urban communities in southwestern Nigeria. Ann. Trop. Med. Parasitol. 104, 5:409-19.

Webbe, G, El Hak, S, 1990: Progress in control of schistosomiasis in Egypt 1985-1988. Trans. Roy. Soc. Trop. Med. Hyg. 84: 394-400.

WHO, 1998: A field guide to African Freshwater snails: Danish Bilharziasis Laboratory. WHO collaborating Centre for Applied Malacology, Charlottenlund, Denmark

WHO, 2011: Preventive Chemotherapy Databank. http://www. who.int/neglected_diseases/ pr eventive_chemotherapy/databank/en/index.html.

WHO, 2012: Schistosomiasis. Fact Sheet. No 115.

Wright, W, 1973: Geographical distribution of schistosomes and their intermediate host. Ansari N, ed. In: Epidemiology and control of schistosomiasis Baltimore: University Park Press.

\section{Explanation of figures}

Fig. 1, 2: Maps showing the location of Tamwah village, Giza Governorate

Fig. 3: A suggestion for isolating the shore $(700 \mathrm{~m})$, the source of infection, by building a high and strong fence along $700 \mathrm{~m}$ length and establishing a fish farm $(700 \times 100 \mathrm{~m}$ area $)$.

Fig. 4: Ended side of Nile River branch, main source of infection with cercariae of $S$. haematobium.

Fig. 5: An aquatic bulldozer removed vegetation in water and act as a good shelter for snails.

Fig. 6: Women attended to Nile for washing dishes and carpets.

Fig. 7: Schistosoma haematobium ovum.

Fig. 8: Virgulate xiphidiocercariae.

Fig. 9: Furcocercus cercaria of S.haematobium

Fig. 10: Bulinus truncatus 

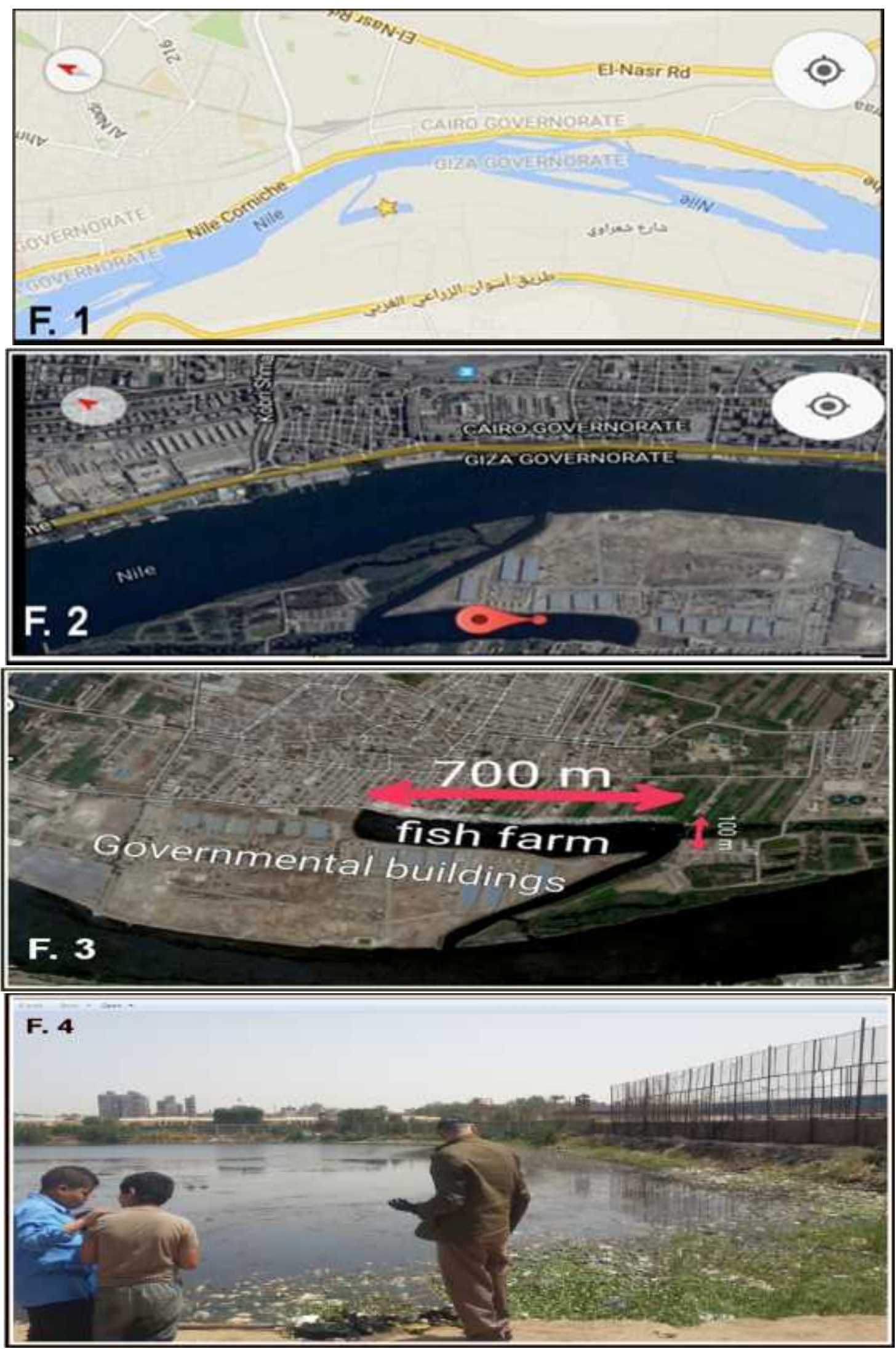


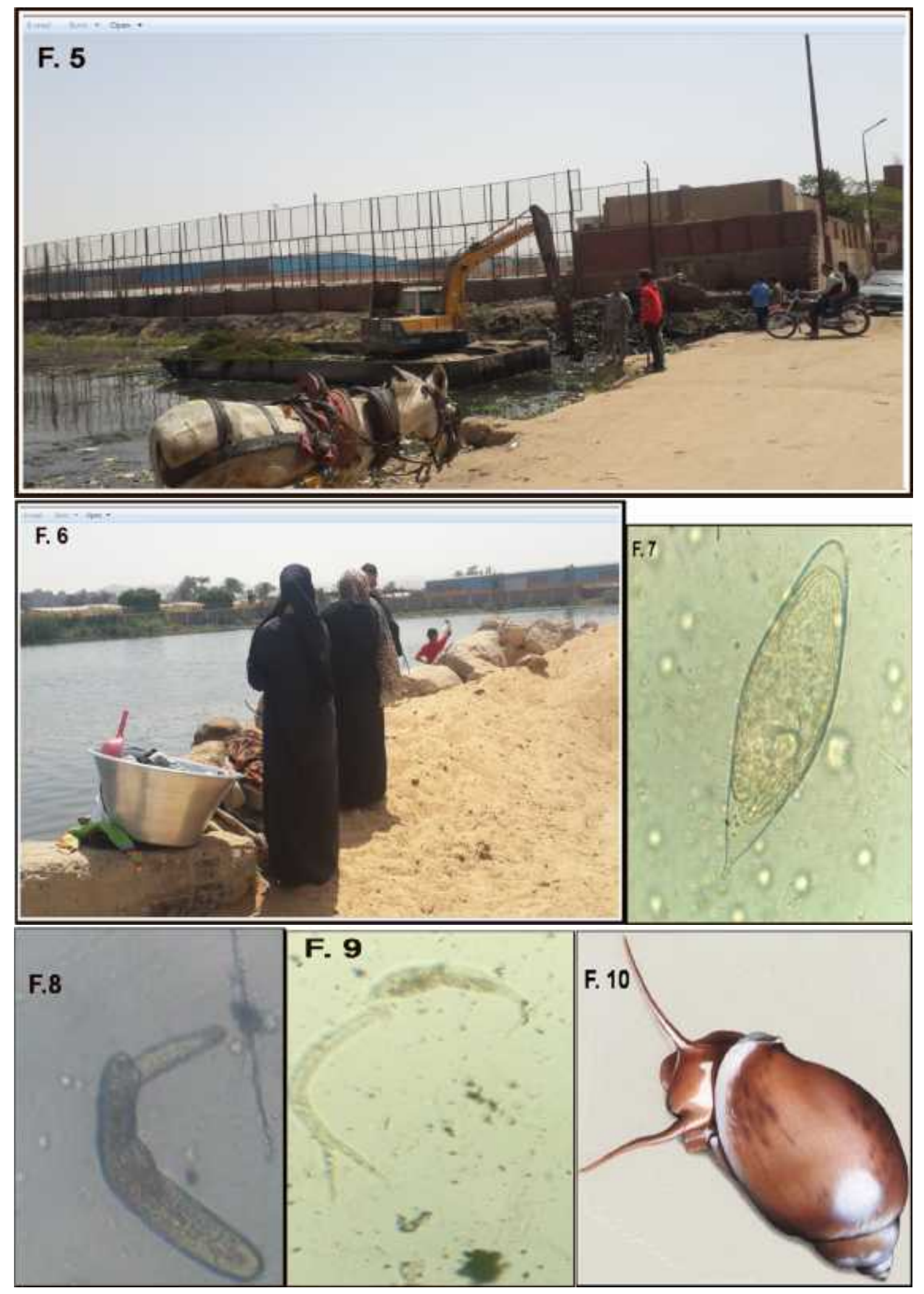

